
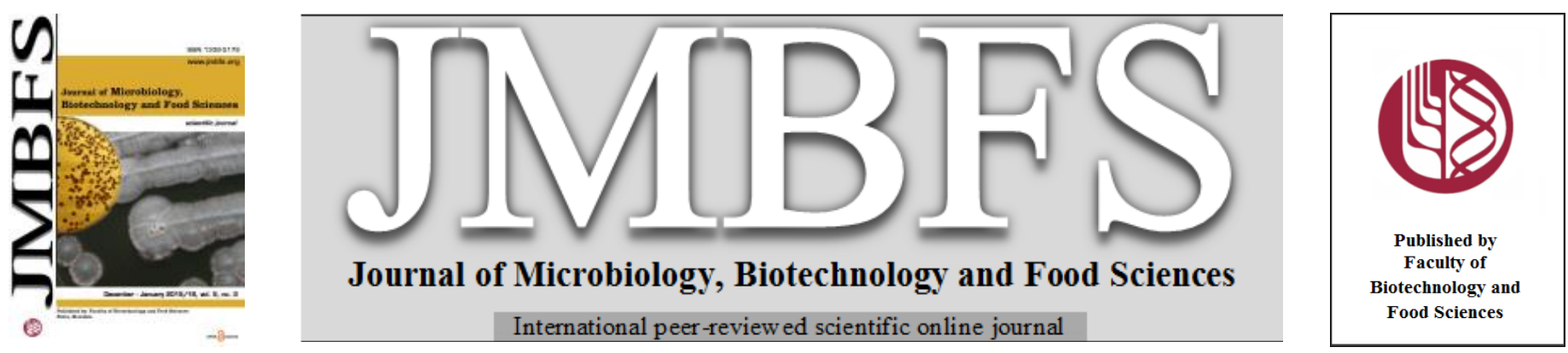

\title{
ANALYSIS OF THE BACTERIAL EPIPHYTIC MICROBIOTA OF OAK LEAF LETTUCE WITH 16S RIBOSOMAL RNA GENE ANALYSIS
}

\author{
Agnes Weiss $^{I^{*}}$, Felix Scheller ${ }^{l}$, Markus Oggenfuss ${ }^{2}$, Fiona Walsh ${ }^{2, \S}$, Jürg E. Frey $^{2}$, David Drissner ${ }^{3}$, Herbert Schmidt ${ }^{l}$ \\ Address(es): Dipl.-Ing. Dr. Agnes Weiss \\ ${ }^{1}$ Department of Food Microbiology and Hygiene, Institute of Food Science and Biotechnology, University of Hohenheim, Garbenstrasse 28, 70599 Stuttgart, Germany, \\ Tel.: +49711459 24255, Fax: +49 71145924199 . \\ ${ }^{2}$ Institute for Plant Production Sciences, and ${ }^{3}$ Institute for Food Sciences, Agroscope, Schloss 1, 8820 Waedenswil, Switzerland.
}

*Corresponding author: agnes.weiss@uni-hohenheim.de

doi: 10.15414/jmbfs.2015/16.5.3.271-276

ARTICLE INFO

Received 15. 5. 2015

Revised 12. 10. 2015

Accepted 14. 10. 2015

Published 1. 12. 2015

Regular article

open $\partial_{\text {ACCESS }}$

\section{ABSTRACT}

The leaf microbiota has major influences on the quality of ready-to-eat lettuce. While studies investigating the epi- and endophytic microbiota of lettuce have been published, no protocols focusing only on the epiphytic microbiota exist. As the epiphytic microbiota may be especially influenced by technological steps in the production of ready-to-eat lettuce, an in-depth knowledge of these microorganisms is essential with regard to consumer safety and spoilage. Currently it is not clear to what extent results gained from single samples are representative of the community composition. A technique for the separation of bacterial cells from the leaf surface was applied to green oak leaf lettuce. The bacterial diversity was analysed in triplicate with high throughput Roche 454 sequencing of prokaryotic 16S rRNA genes to analyse the intra-sample variation. Sequence analysis revealed members of the phyla Acidobacteria, Actinobacteria, Bacteroidetes, Firmicutes, Gemmatimonadetes, Proteobacteria and Verrucomicrobia, and of the candidate division WYO. The ten most abundant proteobacterial genera in all three samples were Alkanindiges (24.6\%), Pseudomonas (11.3\%), Sphingomonas (8.6\%), Janthinobacterium (8.3\%), Acinetobacter (4.3\%), Polaromonas (1.3\%), Erwinia (1.1\%), and Methylobacterium (1.1\%). The genera Pedobacter (2.5\%) and Hymenobacter (1.4\%) dominated the phylum Bacteroidetes. The intra-sample variation was less than $0.7 \%$ for seven of these most abundant genera with the exception of Pseudomonas, Janthinobacterium and Alkanindiges, where larger standard deviations were obtained. This low intra-sample variation demonstrates that the established technique based on oak leaf lettuce is suitable for the culture-independent analysis of the epiphytic bacterial microbiota of produce.

Keywords: Oak leaf lettuce; microbiota; biodiversity; next generation sequencing; Alkanindiges

\section{INTRODUCTION}

The microbial community of plant leaves comprises bacteria, yeast and fungi, which originate from diverse environmental sources such as soil, water, and air. The microbes exhibit commensal, mutualistic, or pathogenic characteristics towards the plant, whereby most of the interactions are commensal (Lindow and Brandl, 2003; Vorholt, 2012). Bacterial viable counts of up to $10^{7}$ colony forming units per gram of leaf have been described (Thunberg et al., 2007; Wulfkuehler et al., 2013 and 2014). According to Williams et al. (2013), only $1 \%$ to $10 \%$ of the total bacteria on leaves are cultivable. Thus, the results obtained by culture-dependent methods clearly differ from those determined by culture-independent sequence-based methods. Using culture-independent sequence-based methods the bacterial communities from several plants such as lettuce, spinach, rice, diverse tree species, and Arabidopsis thaliana, were investigated. These studies revealed that Proteobacteria, Firmicutes, Actinobacteria and Bacteroidetes were the most abundant phyla across plant bacterial communities (Knief et al., 2012; Lopez-Velasco et al., 2011; Rastogi et al., 2012; Redford et al., 2010; Reisberg et al., 2012; Williams et al., 2013). At the genus level, mainly Pseudomonas, Sphingomonas, Methylobacterium, Bacillus, Massilia, Arthrobacter, Pantoea, and Erwinia were found. Sphingomonas and Methylobacterium have been demonstrated as being the most abundant genera of the bacterial communities on leaves in a multitude of plant species including important crop plants like clover, soybean, tomato, rice, and several grassland species (Delmotte et al., 2009; Enya et al., 2007; Green, 2005; Kim et al., 1998).

Several techniques have been used to analyse community changes as a function of exogenous and endogenous factors such as geography, climate, radiation, and plant genetics (Finkel et al., 2012; Hunter et al., 2010; Izhaki et al., 2013; Kadivar and Stapleton, 2003; Knief et al., 2012; Rastogi et al., 2012; Redford et al., 2010; Vokou et al., 2012).
In the present study, we developed an extensive protocol from sample preparation to next generation sequencing to assess the bacterial diversity on the surface of oak leaf lettuce. This cultivar was chosen as an example of a cultivar with a delicate leaf structure. A procedure for the separation of the bacterial cells from the leaf surfaces while retaining leaf integrity was established. A biodiversity analysis using Roche 454 sequencing of 16S rRNA gene amplicons was performed. This procedure was evaluated with DNA retrieved from a single green oak leaf lettuce head to determine the reproducibility of the method and to determine the degree of intra-sample variation within a single lettuce sample.

\section{MATERIAL AND METHODS}

\section{Bacterial biomass harvest and DNA isolation}

One head of conventionally grown green oak leaf lettuce (Lactuca sativa var crispa) was obtained from a local retail store. The wrapper leaves were removed under sterile conditions by cutting with a scalpel. To gain a representative amount of biomass, ten middle-sized leaves from this lettuce head were used as described below. DNA was isolated from each of the leaves and the DNA preparations were subsequently combined to a single DNA solution.

Bacterial biomass harvest was carried out as follows: the cut edges of ten middlesized leaves (approximately $10 \mathrm{~g}$ of lettuce each) were sealed with commercial nail polish (Manhattan Lotus Effect, Coty Germany GmbH, Germany) to reduce chloroplast effusion. The leaves were transferred into sterile blender bags with lateral filters (BBAG-03, Gosselin SAS, France) and the appropriate nine-fold volume of sterile buffer (1\% (w/v) TWEEN ${ }^{\circledR} 80$ (Sigma-Aldrich Co., U.S.A.), $1 \%(\mathrm{w} / \mathrm{v})$ buffered peptone water (Merck KGaA, Germany), $10 \mathrm{mM}$ EDTA (Biomol GmbH, Germany); pH 6.7) was added. The leaves were completely covered by the buffer. The bags were then heat-sealed and placed into a Pulsifier ${ }^{\circledR}$ PUL 100E device (Microgen Bioproducts Ltd., UK), and treated for 45 $\mathrm{s}$ to detach microorganisms from the leaf surface. With this procedure, removal 
of bacteria was highest and leaves remained largely intact (data not shown). Afterwards, the complete buffer of each leaf was divided into two equal volumes, which were transferred into two sterile $50 \mathrm{~mL}$ centrifuge tubes. The tubes were centrifuged at $8,000 \times g$ for $20 \mathrm{~min}$ at $4^{\circ} \mathrm{C}$. Supernatants were discarded, and the four cell pellets of two leaves were pooled into $2 \mathrm{~mL}$ reaction tubes, resulting in five tubes, and stored at $-20^{\circ} \mathrm{C}$.

Genomic DNA was prepared from the five cell pellets modified from Wilson (1997). Each bacterial cell pellet was re-suspended in $567 \mu \mathrm{L}$ lysozyme solution ( $3 \mathrm{mg} / \mathrm{mL}$ in TE-buffer (10 mM Tris, $1 \mathrm{mM}$ EDTA; $\mathrm{pH} 8.0)$ ) by vigorous blending. After the addition of cetyl trimethylammonium bromide (CTAB) and $0.7 \mathrm{M}$ sodium chloride and incubation at $65^{\circ} \mathrm{C}$ for $10 \mathrm{~min}$, the samples were cooled to room temperature, and $50 \mu \mathrm{L}$ of ribonuclease A solution $(3 \mathrm{mg} / \mathrm{mL}$ in TE-buffer) was added. The samples were mixed and incubated at $37^{\circ} \mathrm{C}$ for $2 \mathrm{~h}$. The first extraction step was performed with $800 \mu \mathrm{L}$ of a mixture of phenol:chloroform:isoamyl alcohol (25:24:1) (Carl Roth $\mathrm{GmbH} \&$ Co. KG Germany) by mixing and centrifugation in a bench top centrifuge $(17,950 \times g$ $4^{\circ} \mathrm{C}, 5 \mathrm{~min}$ ). The upper aqueous phase was transferred into a fresh tube and 800 $\mu \mathrm{L}$ of chloroform:isoamyl alcohol (24:1) (Carl Roth GmbH \& Co. KG) were added. The sample was mixed and centrifuged under the same conditions as described above. The aqueous phase was again transferred to a new tube and this step was repeated once. Finally, $600 \mu \mathrm{L}$ of ice-cold isopropanol $\left(-20^{\circ} \mathrm{C}\right.$; Merck $\mathrm{KGaA}$ ) was added and the DNA was precipitated for at least $0.5 \mathrm{~h}$ at $-20^{\circ} \mathrm{C}$. The precipitate was centrifuged $\left(17,950 \times g, 4^{\circ} \mathrm{C}, 15 \mathrm{~min}\right)$, the supernatant was discarded, and the pellet was washed with $1 \mathrm{~mL}$ of $70 \%(\mathrm{v} / \mathrm{v})$ ethanol $\left(-20^{\circ} \mathrm{C}\right)$ The dried pellet was re-suspended in $40 \mu \mathrm{L}$ of DNase- and RNase-free sterile water (Gibco ${ }^{\circledR}$, Thermo Fisher Scientific Inc.) and stored at $4{ }^{\circ} \mathrm{C}$ overnight. The DNA was solubilised by heating at $65^{\circ} \mathrm{C}$ for $5 \mathrm{~min}$. The solutions of the five parallel samples were pooled, dried with a SpeedVac ${ }^{\mathrm{TM}}$ Vacuum System (Thermo Fisher Scientific Inc.) at ambient temperature and re-suspended in $40 \mu \mathrm{L}$ of DNase- and RNase-free sterile water. The DNA concentration and quality were determined with a NanoDrop ${ }^{\mathrm{TM}}$ ND-2000 device (PEQLAB Biotechnologie $\mathrm{GmbH}$, Germany) and by agarose gel electrophoresis.

\section{Amplification of 16S rRNA genes, library preparation and Roche 454 sequencing}

The primers for the paired-end $16 \mathrm{~S}$ rRNA gene community sequencing were 515F (5'-GTGCCAGCMGCCGCGGTAA-3') and 806R (5' GGACTACHVGGGTWTCTAAT-3') (Caporaso et al., 2012). Three samples of the DNA solution were used for Roche 454 sequencing. For each of the three samples, four different PCRs were performed to reduce the bias using dilutions of the purified DNA at concentrations of $10^{-1}, 10^{-2}, 10^{-3}$, and $10^{-4}$. Each $25 \mu \mathrm{L}$ reaction contained $200 \mathrm{nM}$ of each primer, $1 \mu \mathrm{L}$ of template DNA as indicated above, $10 \mu \mathrm{L}$ of 5 PRIME HotMasterMix (5 PRIME GmbH, U.S.A.), and $13 \mu \mathrm{L}$ of PCR grade water. PCR cycle parameters consisted of an initial denaturation at $94^{\circ} \mathrm{C}$ for $3 \mathrm{~min}$, then 35 cycles of denaturation at $94^{\circ} \mathrm{C}$ for $45 \mathrm{~s}$, annealing at $50^{\circ} \mathrm{C}$ for $1 \mathrm{~min}$ and extension at $72^{\circ} \mathrm{C}$ for $1.5 \mathrm{~min}$, followed by a final extension step at $72^{\circ} \mathrm{C}$ for $10 \mathrm{~min}$, as described on the Earth Microbiome website (http://www.earthmicrobiome.org/emp-standard-protocols/16S).

PCR products were obtained from template dilutions of $10^{-2}, 10^{-3}$ and $10^{-4}$. These products were pooled for each sample separately $(55 \mu \mathrm{L}$ each), mixed with 275 $\mu \mathrm{L}$ of PB buffer (Qiagen GmbH, U.S.A.), and purified using a MinElute ${ }^{\circledR}$ PCR Purification Kit (Qiagen $\mathrm{GmbH}$ ) according to the manufacturer's protocol. The amplicons were eluted with $20 \mu \mathrm{L}$ of PCR grade water and quantified with a NanoDrop ${ }^{\circledR}$ ND-1000 spectrophotometer (Thermo Fisher Scientific Inc.). The concentrations of the three samples were 50,35 and $50 \mathrm{ng} / \mu \mathrm{L}$, respectively. The following steps were performed for each sample independently: For the fragment end repair, $500 \mathrm{ng}$ of purified amplicon was used and an adaptor ligation was carried out according to the Rapid Library Preparation Method Manual V. 3/2012 (F. Hoffmann-La Roche Ltd., Switzerland). The resulting sample $(27 \mu \mathrm{L})$ was mixed with $3 \mu \mathrm{L}$ of BlueJuice ${ }^{\mathrm{TM}}$ gel loading buffer (Thermo Fisher Scientific Inc.), run on a $1 \%$ agarose $[$ TAE $1 \times]$ gel for $40 \mathrm{~min}$ at $4.5 \mathrm{~V} / \mathrm{cm}$. The ligation product was excised on a DarkReader ${ }^{\circledR}$ transilluminator (Clare Chemical Research, U.S.A.) and recovered using the MinElute ${ }^{\circledR}$ Gel Extraction Kit (Qiagen $\mathrm{GmbH}$ ). Library quantitation was performed according to the Roche Manual with a QuantiFluor TM ST fluorimeter (Promega, U.S.A.). An aliquot of the DNA library was diluted to a working stock of $1 \times 10^{7}$ molecules $/ \mu \mathrm{L}$ in TE buffer. An emulsion PCR was then performed with $11 \mu \mathrm{L}$ of a working stock according to the emPCR Amplification Method Manual - Lib-L V. 3/2012 (F. Hoffmann-La Roche Ltd.). DNA library bead enrichment and sequencing primer annealing were performed according to the manufacturer's specifications using a REM-e module (F. Hoffmann-La Roche Ltd.) on a Biomek ${ }^{\circledR} 3000$ robot (Beckman Coulter GmbH, U.S.A.). Finally, the parallel samples were independently sequenced on a 454 GS Junior System (F. Hoffmann-La Roche Ltd.) according to the Sequencing Method Manual V. 1/2013 (F. Hoffmann-La Roche Ltd.)

\section{S rRNA amplicon sequencing data analysis}

Forward and reverse reads were joined using fastq-join from the ea-utils software package (Aronesty, 2011). The sequences were then quality-filtered to exclude sequences with ambiguous bases $(\mathrm{N})$ and sequences containing base calls with less than 99\% confidence (Phred score of < 20). The QIIME bioinformatics software suite (version 1.5.0) was used to subsample the resultant sequences $(82,311,99,654$ and 95,216 sequences, respectively), to cluster those sequences into $97 \%$ identity operational taxonomic units (OTU) with UCLUST (Aronesty, 2011), to taxonomically classify each OTU with RDP classifier (Edgar 2010) at $97 \%$ sequence homology placement into the GreenGenes 12_10 database (DeSantis et al., 2006). All QIIME scripts were run using default parameters unless otherwise stated. The sequences were deposited in the NCBI sequence read archive (SRA) under the numbers SRR1523744 (sample 1), SRR1265099 (sample 2) and SRR1265426 (sample 3).

\section{RESULTS AND DISCUSSION}

\section{S rRNA gene amplicon sequencing results}

In order to assess a method for the biodiversity analysis of leaf surface microbiota and to measure intra-sample variation, the total DNA of the leaf surface microbiota of a single lettuce head was isolated and quantified. A DNA concentration of $2,727.4 \mathrm{ng} / \mu \mathrm{L}$ with absorption ratios of $\mathrm{A}_{260} / \mathrm{A}_{280}$ of 1.85 and $\mathrm{A}_{260} / \mathrm{A}_{230}$ of 1.77 were obtained for the pooled DNA solution. Three samples of this DNA solution, called sample 1, sample 2 and sample 3, were analysed by 16S rRNA gene sequencing using a Roche 454 next generation sequencer as described above. The universal primers used have been described to cover the variable region 4 of the 16S rRNA gene of almost all bacterial phyla (Walters $\boldsymbol{e}$ al. 2011). The results and quality parameters of these runs are depicted in Table 1.

Table 1 16S rRNA gene amplicon sequencing result

\begin{tabular}{|c|c|c|c|}
\hline $\begin{array}{l}\text { Sequence analysis } \\
\text { parameters }\end{array}$ & Sample 1 & Sample 2 & Sample 3 \\
\hline $\begin{array}{l}\text { Total sequences } \\
\text { (OTUs) }\end{array}$ & $\begin{array}{l}82,311 \\
(1,355 \\
\text { OTUs) }\end{array}$ & $\begin{array}{l}99,654 \\
(1,667 \\
\text { OTUs) }\end{array}$ & $\begin{array}{c}95,216 \\
(1,364 \text { OTUs })\end{array}$ \\
\hline $\begin{array}{l}\text { Median length of } \\
\text { sequences [bp] }\end{array}$ & 266 & 291 & 268 \\
\hline $\begin{array}{l}\text { Phred Score } \pm \text { standard } \\
\text { deviation }\end{array}$ & $36.73 \pm 6.40$ & $36.94 \pm 6.12$ & $37.07 \pm 6.03$ \\
\hline Covered richness (Chao1) & 4644.0 & 5478.2 & 2370.2 \\
\hline $\begin{array}{l}\text { Phylogenetic distance (PD) } \\
\text { estimator }\end{array}$ & 66.0 & 87.8 & 66.3 \\
\hline Shannon's $H$ index & 5.7 & 5.9 & 5.8 \\
\hline $\begin{array}{l}\text { Mitochondrial sequences } \\
\text { (OTUs) } \\
\text { Chloroplast sequences } \\
\text { (OTUs) }\end{array}$ & $\begin{array}{c}129 \\
(10 \text { OTUs) } \\
10,992 \\
\text { (29 OTUs) }\end{array}$ & $\begin{array}{c}192 \\
(21 \text { OTUs) } \\
9,853 \\
\text { (15 OTUs) }\end{array}$ & $\begin{array}{c}169 \\
(14 \text { OTUs) } \\
15,468 \\
\text { (20 OTUs) }\end{array}$ \\
\hline $\begin{array}{l}\text { Bacterial 16S rRNA gene } \\
\text { sequences (OTUs) }\end{array}$ & $\begin{array}{l}71,190 \\
(1,316 \\
\text { OTUs) }\end{array}$ & $\begin{array}{l}89,609 \\
(1,631 \\
\text { OTUs) }\end{array}$ & $\begin{array}{c}79,579 \\
(1,330 \text { OTUs })\end{array}$ \\
\hline $\begin{array}{l}\text { of these } \\
\text { Abundant OTUs }\end{array}$ & 396 & 472 & 489 \\
\hline $\begin{array}{l}\text { Sequences in abundant } \\
\text { OTUs }\end{array}$ & 69,284 & 87,954 & 77,947 \\
\hline $\begin{array}{l}\% \text { of bacterial } 16 \mathrm{~S} \text { rRNA } \\
\text { gene sequences }\end{array}$ & 97.3 & 98.1 & 97.9 \\
\hline $\begin{array}{l}\% \text { of bacterial } 16 \mathrm{~S} \text { rRNA } \\
\text { gene OTUs }\end{array}$ & 30.1 & 28.9 & 36.8 \\
\hline
\end{tabular}

On average, 92,393 sequences were obtained per sample, with an average median length of 275 bp. Members of the domain Archaea were not detected, and the sequences assigned to eukaryotes originated from their mitochondria and chloroplasts (see Table 1). The covered richness expressed as the Chaol index was rather high, reaching an average of 4164.1. For all samples the rarefaction curves showed asymptotic curve progression, indicating that a very high bacterial diversity was detected in this study (Figure 1). As expected, the total number of sequences included mitochondrial as well as chloroplast sequences (see Table 1), which were discarded from the subsequent analysis. Furthermore, sequences that could not be assigned to a phylum or a candidate division were excluded from the analysis. The mean number of bacterial 16S rRNA gene sequences was therefore 80,126. These data indicate a high level of taxonomic identification and classification with the method applied as well as that the applied database was very appropriate with respect to the analysed samples. 

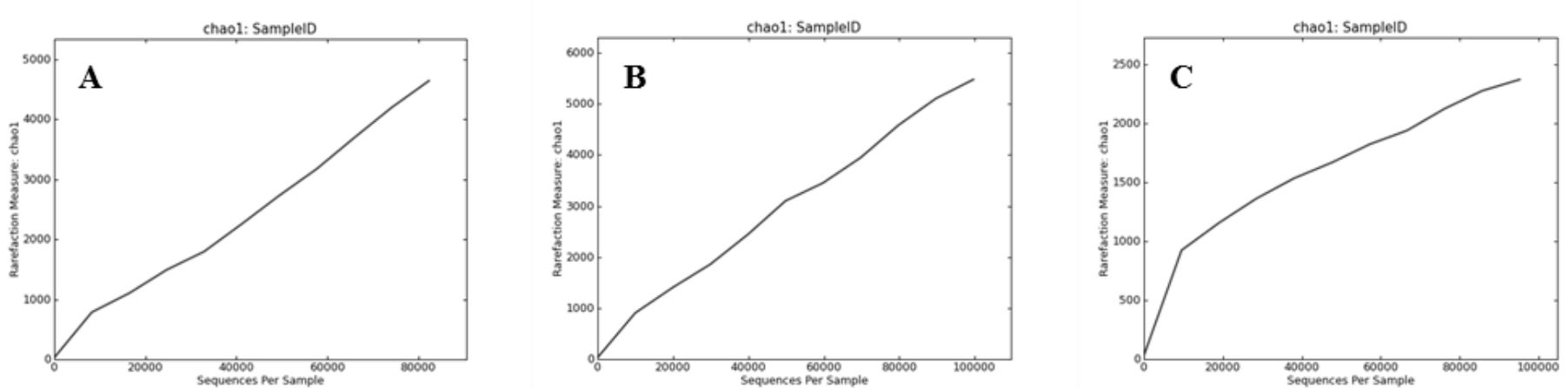

Figure 1 Rarefaction curves showing the covered richness expressed as the Chao1 index for the samples 1 (A), 2 (B) and 3 (C)

The data obtained by next generation sequencing were evaluated for the intrasample variation. Approximately 450 OTUs per sample were detected. This demonstrates a diverse microbiota present on oak leaf lettuce, as the majority of sequences could be assigned to specific bacterial phyla. The number of sequences that remained unclassified or could only be assigned to the kingdom Bacteria strongly declined with increasing number of sequences per OTU in all samples. It has to be noted that diversity estimates are highly sensitive to the abundance of rare members of populations (White $\boldsymbol{e t}$ al., 2010). Including OTUs with single reads into the evaluation, Kunin et al. (2010) found that sequencing errors inflated the actual diversity 100-fold, and therefore the present analysis was restricted to OTUs containing at least five sequences. Of the remaining OTUs on average six unclassified OTUs consisted of more than five sequences. For the kingdom Bacteria on average twelve OTUs with more than five sequences were found that could not be assigned to a further taxonomic level. These may represent hitherto unidentified bacteria, but might also be attributed to sequencing errors that were not removed from the dataset despite de-noising.

\section{Phylogenetic analysis of abundant OTUs}

The results gained from the three analysed samples were compared to determine the intra-sample variation. On average 452 OTUs contained at least five sequences, which corresponded to $32.0 \%$ of the bacterial $16 \mathrm{~S}$ rRNA gene OTUs (see Table 1). Nevertheless, these OTUs contained on average $97.8 \%$ of the bacterial 16S rRNA gene sequences. Furthermore, on average $0.4 \%$ could be identified on the kingdom level as Bacteria only and could not be assigned to a specific phylum (Table 2).

Among the abundant OTUs sequences members of the phyla Acidobacteria, Actinobacteria, Bacteroidetes, Firmicutes, Gemmatimonadetes, Proteobacteria, and Verrucomicrobia as well as the candidate division WYO were detected. As shown in Table 2, $89.9 \pm 1.0 \%$ of the sequences belonged to the phylum Proteobacteria, followed by the phyla Bacteroidetes $(7.1 \pm 1.0 \%)$ and Actinobacteria $(2.5 \pm 0.4 \%)$. Only a minority of sequences was allocated to the remaining phyla. Within the Proteobacteria, on average $56.0 \%$ of the sequences were $\gamma$-Proteobacteria, $16.8 \% \beta$-Proteobacteria, and $15.9 \% \alpha$-Proteobacteria while only $0.1 \%$ of the sequences were $\delta$-Proteobacteria. Only one OTU in sample 3 containing five sequences was allocated to $\varepsilon$-Proteobacteria, to the genus Arcobacter.

Table 2 Number of classified sequences allocated to abundant OTUs, respective number of OTUs and genera assigned to diverse phyla and their proportion within the of bacterial 16S rRNA gene sequences contained in abundant OTUs [\%]

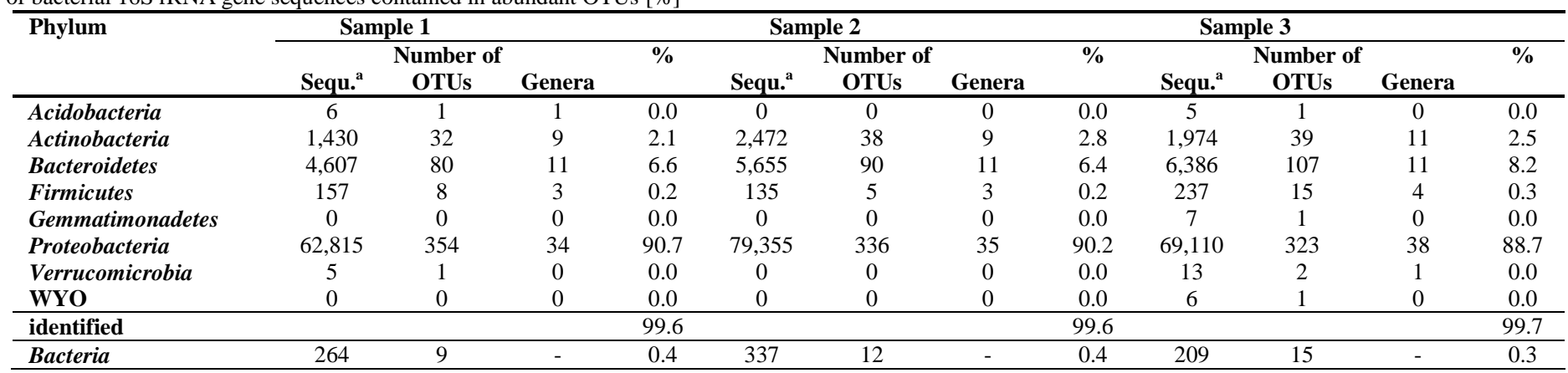

${ }^{a}$ Sequ.: sequences.

The phyla detected in the current study match those reported for Romaine lettuce (Rastogi et al., 2012) and greenhouse-grown lettuce (Erlacher et al., 2014) for the total leaf microbiota of endophytic and epiphytic microorganisms, but, as expected, the composition differed. The majority of sequences were assigned to Gram-negative bacteria. This is in accordance with results of other authors (e.g., Rastogi et al., 2012; Vorholt, 2012), even though more members of the phylum Firmicutes were reported. The focus of this work was on the Gram-negative population, as several members are known to produce biofilms and to be responsible for spoilage. Nevertheless, the DNA isolation procedure applied in the present study was re-assessed with a panel of selected representative Grampositive and -negative pure cultures. Furthermore, harsher DNA isolation procedures including bead-beating steps were evaluated for epiphytic phyllosphere community biomass samples, which yielded inferior DNA quality (data not shown). Cruaud et al. (2014) found in their comparison of a commercial DNA isolation kit with a conventional DNA isolation procedure for application in 454 pyrosequencing only low levels of dissimilarity in taxonomic affiliations. Furthermore, the primers applied in the current study should also have amplified Gram-positive sequences. The detected low numbers of Grampositives could also be attributed to the leaf type, as the microbiota of lettuce was shown to depend on the cultivar (Hunter et al., 2010), the season (Williams et al., 2013) and the geographical location (Finkel et al., 2011; Redford $e t$ al., 2010)

In total, 58 genera were detected in both, sample 1 and 2, and 65 genera in sample 3 (Table 2). They contained on average $65.6 \%$ of the bacterial $16 \mathrm{~S}$ rRNA gene sequences of abundant OTUs. Of these, only ten genera were assigned at least $1.0 \%$ of the sequences in one of the samples (see Table 3). Of these ten genera, eight were identical in all three samples, and only Methylobacterium and Polaromonas were below $1.0 \%$ in one of the samples. For these ten most abundant genera, the number of sequences of the most abundant OTUs between the samples was comparable. For example, for the genus Alkanindiges two OTUs per sample contained the majority of the sequences. These were 8,665 and 8,610 sequences for sample 1, 10,357 and 9,396 sequences for sample 2 and 10,918 and 8,999 sequences for sample 3 . The only exception was Polaromonas, where only two abundant OTUs were detected in sample 1, and one abundant OTU in each of the other two samples.

Of the Proteobacteria these main genera were the $\alpha$-proteobacterial genera Sphingomonas and Methylobacterium, the $\beta$-proteobacterial genera Janthinobacterium and Polaromonas, as well as the $\gamma$-proteobacterial genera Alkanindiges, Pseudomonas, Acinetobacter, and Erwinia. To display the proteobacterial diversity, Figure 2 compares all proteobacterial genera that amounted at least $0.1 \%$ of the total number of sequences in the three samples. 


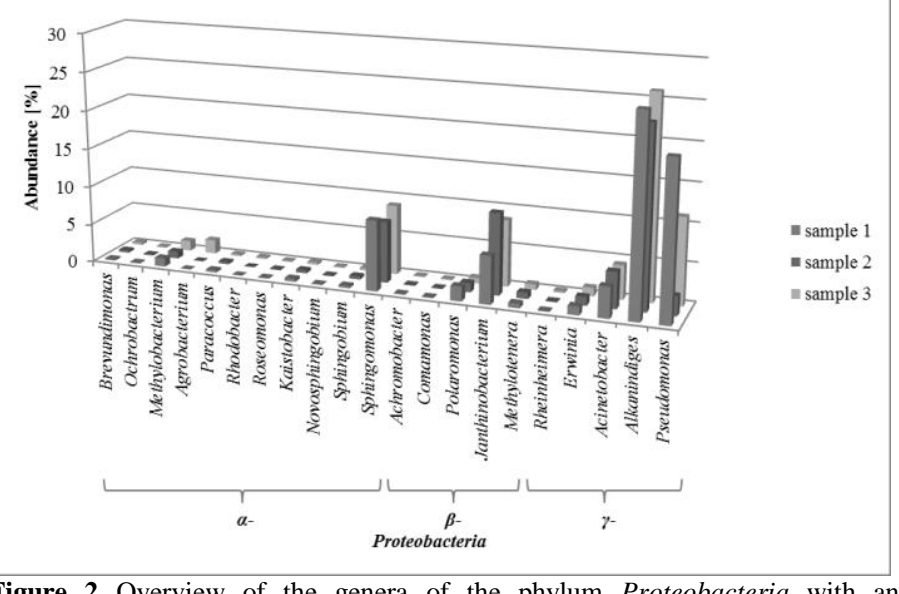

Within the phylum Bacteroidetes the genera Pedobacter and Hymenobacter were most abundant (Table 3). As shown in Table 3, the standard deviations of the abundances were below $0.7 \%$ for seven of the ten genera. Larger standard deviations were calculated for Pseudomonas, Janthinobacterium and Alkanindiges. These results correlate well with higher numbers of sequences identified only at the respective family level (data not shown). For example, $20.5 \%, 2.6 \%$ and $11.2 \%$ of the sequences in abundant OTUs were allocated to the genus Pseudomonas. On the other hand, 3.5\%, 22.4\% and 9.6\% were additionally allocated to the family Pseudomonadaceae, but no genus affiliation was possible.

Figure 2 Overview of the genera of the phylum Proteobacteria with an abundance of at least $0.1 \%$ of the total sequences in one of the samples

Table 3 Number of classified sequences allocated to abundant OTUs, respective number of OTUs assigned to the ten most abundant genera and their proportion within the number of bacterial 16S rRNA gene sequences contained in abundant OTUs [\%]

\begin{tabular}{|c|c|c|c|c|c|c|c|c|c|c|c|}
\hline \multirow[t]{2}{*}{ Genus } & \multicolumn{3}{|l|}{ Sample 1} & \multicolumn{3}{|l|}{ Sample 2} & \multicolumn{3}{|l|}{ Sample 3} & \multirow[t]{2}{*}{ Mean } & \multirow[t]{2}{*}{$\begin{array}{l}\text { St. } \\
\text { dev. }\end{array}$} \\
\hline & $\begin{array}{l}\text { Number of } \\
\text { sequences }\end{array}$ & OTUs & $\%$ & $\begin{array}{l}\text { Number of } \\
\text { sequences }\end{array}$ & OTUs & $\%$ & $\begin{array}{l}\text { Number of } \\
\text { sequences }\end{array}$ & OTUs & $\%$ & & \\
\hline Alkanindiges & 17,860 & 17 & 25.8 & 20,455 & 15 & 23.3 & 20,336 & 19 & 26.1 & 25.1 & 1.5 \\
\hline Pseudomonas & 14,191 & 11 & 20.5 & 2,245 & 15 & 2.6 & 8,745 & 10 & 11.2 & 11.4 & 9.0 \\
\hline Sphingomonas & 6,383 & 17 & 9.2 & 6,956 & 26 & 7.9 & 7,014 & 23 & 9.0 & 8.7 & 0.7 \\
\hline Janthinobacterium & 4,344 & 5 & 6.3 & 9,235 & 7 & 10.5 & 6,691 & 9 & 8.6 & 8.5 & 2.1 \\
\hline Acinetobacter & 2,795 & 15 & 4.0 & 4,136 & 16 & 4.7 & 3,459 & 17 & 4.4 & 4.4 & 0.4 \\
\hline Pedobacter & 1,695 & 5 & 2.4 & 2,012 & 6 & 2.3 & 2,361 & 8 & 3.0 & 2.6 & 0.4 \\
\hline Hymenobacter & 985 & 16 & 1.4 & 1,092 & 17 & 1.2 & 1,321 & 26 & 1.7 & 1.4 & 0.3 \\
\hline Polaromonas & 1,306 & 2 & 1.9 & 1,064 & 1 & 1.2 & 560 & 1 & 0.7 & 1.3 & 0.6 \\
\hline Erwinia & 760 & 2 & 1.1 & 967 & 2 & 1.1 & 852 & 2 & 1.1 & 1.1 & 0.0 \\
\hline Methylobacterium & 782 & 7 & 1.1 & 764 & 7 & 0.9 & 1,044 & 10 & 1.3 & 1.1 & 0.2 \\
\hline
\end{tabular}

The most abundant bacterial genus was Alkanindiges, a $\gamma$-Proteobacterium, which comprised on average $25.1 \pm 1.5 \%$ of the bacterial $16 \mathrm{~S}$ rRNA gene sequences in abundant OTUs. No species affiliation within this genus was possible in all samples. This genus was already reported to be an important member of the leaf microbiota of Romaine lettuce (Rastogi et al., 2012), and in the former study its presence correlated positively with that of Xanthomonas campestris pv. vitians. Contrarily, although Alkanindiges was the most abundant genus in the present study, no Xanthomonas sequences were detected. On the other hand, Alkanindiges and Acinetobacter were reported as indicators for healthy plants (Erlacher et al., 2014), and it should be studied further if the difference in Alkanindiges abundance could be attributed to the lettuce cultivar and growth conditions. The only genus of the family Enterobacteriaceae among the ten most abundant genera was Erwinia. Erwinia may cause plant disease, be saprophytic or epiphytic, depending on the species (Hauben and Swings, 2005) It is commonly found on lettuce (Rastogi et al., 2012), and the presence of Erwinia on Romaine lettuce was hypothesized to correlate with a decreased survival of E. coli O157:H7 (Williams et al., 2013). Escherichia was only rarely detected on Romaine lettuce (Williams $\boldsymbol{e t}$ al., 2013), which is also the case in the current study. Each sample contained only one OTU of Escherichia, with 25, 1 and 27 sequences, respectively.

The $1,192,1,254$ and 1,142 sequences allocated to rare OTUs amounted to $1.5 \%$ of the total bacterial 16S rRNA gene sequences on average. Table 4 gives an overview of the assignment of rare OTUs to the diverse phyla and candidate divisions. On average, only $744(0.9 \%)$ single reads were found.

Table 4 Number of classified sequences allocated to rare OTUs, respective number of OTUs and genera assigned to diverse phyla and candidate divisions

\begin{tabular}{|c|c|c|c|c|c|c|c|c|c|}
\hline \multirow[t]{2}{*}{ Phylum } & \multicolumn{3}{|l|}{ Sample 1} & \multicolumn{3}{|l|}{ Sample 2} & \multicolumn{3}{|l|}{ Sample 3} \\
\hline & $\begin{array}{l}\text { Number of } \\
\text { Sequences }\end{array}$ & OTUs & Genera & $\begin{array}{l}\text { Number of } \\
\text { Sequences }\end{array}$ & OTUs & Genera & $\begin{array}{l}\text { Number of } \\
\text { Sequences }\end{array}$ & OTUs & Genera \\
\hline Acidobacteria & 13 & 10 & 1 & 21 & 17 & $\overline{1}$ & 18 & 12 & 1 \\
\hline Actinobacteria & 95 & 70 & 11 & 116 & 89 & 17 & 92 & 58 & 14 \\
\hline Armatimonadetes & 3 & 1 & 0 & 1 & 1 & 1 & 4 & 2 & 0 \\
\hline Bacteroidetes & 158 & 117 & 12 & 183 & 128 & 13 & 210 & 115 & 15 \\
\hline $\mathrm{BRC} 1^{\mathrm{a}}$ & 0 & 0 & 0 & 1 & 1 & 0 & 0 & 0 & 0 \\
\hline Chlamydiae & 0 & 0 & 0 & 2 & 2 & 1 & 0 & 0 & 0 \\
\hline Chlorobi & 0 & 0 & 0 & 0 & 0 & 0 & 7 & 2 & 0 \\
\hline Chloroflexi & 5 & 4 & 0 & 6 & 6 & 0 & 5 & 4 & 0 \\
\hline Firmicutes & 26 & 21 & 9 & 70 & 52 & 10 & 42 & 25 & 11 \\
\hline Gemmatimonadetes & 9 & 8 & 1 & 7 & 7 & 0 & 14 & 12 & 0 \\
\hline Nitrospirae & 1 & 1 & 1 & 5 & 4 & 1 & 2 & 2 & 1 \\
\hline Planctomycetes & 12 & 10 & 1 & 11 & 11 & 3 & 16 & 11 & 1 \\
\hline Proteobacteria & 664 & 510 & 38 & 802 & 631 & 42 & 714 & 433 & 40 \\
\hline Tenericutes & 5 & 2 & 0 & 4 & 2 & 0 & 1 & 1 & 0 \\
\hline Thermi & 4 & 2 & 2 & 3 & 3 & 1 & 4 & 3 & 1 \\
\hline $\mathrm{TM} 7^{\mathrm{b}}$ & 1 & 1 & 0 & 0 & 0 & 0 & 0 & 0 & 0 \\
\hline Verrucomicrobia & 15 & 13 & 3 & 19 & 15 & 0 & 8 & 5 & 1 \\
\hline $\mathrm{WS}^{\mathrm{c}}$ & 0 & 0 & 0 & 2 & 2 & 0 & 0 & 0 & 0 \\
\hline $\mathrm{WYO}^{\mathrm{d}}$ & 4 & 2 & 0 & 1 & 1 & 0 & 5 & 3 & 0 \\
\hline
\end{tabular}

${ }^{a}$ Bacterial Rice Cluster 1 (Derakshani et al., 2001)

${ }^{\mathrm{b}}$ Torf, mittlere Schicht 7 (Rheims et al., 1996)

${ }^{c}$ Wurtsmith Aquifer 3 (Dojka et al., 1998)

${ }^{\mathrm{d}}$ Wyoming soil clone (Mummey and Stahl, 2003) 
As expected by the length of the sequenced amplicons, a species affiliation was possible in $26.2 \%$ (36 OTUs), $7.7 \%$ (34 OTUs) and $16.1 \%$ (48 OTUs) of the sequences of the three samples. These were mainly associated with the mos abundant genera, and therefore no separate evaluation was carried out Furthermore, no correlation was found between the abundance of rRNA gene sequences detected in this study and the mean number of rRNA genes present in the respective genus (Lee et $\boldsymbol{a l}$. , 2008). As expected, the standard deviations between the samples and thus the intra-sample variation increased with the taxonomic level from phylum to genus. This could be attributed to the length of the sequenced amplicons. In this study a method published within the Earth Microbiome Project was applied to evaluate it for studying the plant microbiota, too. For further decreasing the intra-sample variation it could be considered to study longer amplicons, as they might facilitate a higher taxonomic resolution. Thus it was demonstrated that the established procedure consisting of bacteria biomass harvest, DNA isolation and next generation sequencing is indeed suitable for the biodiversity analysis of the epiphytic bacterial microbiota of lettuce.

\section{CONCLUSION}

In this study a complete procedure for the assessment of the bacterial leaf surface microbiota of lettuce was successfully established. Comparable results with low intra-sample variation are obtained with the established protocol by analysing three samples of the same lettuce head. In the current study, $\gamma$-Proteobacteria were most abundant, as already reported for other lettuce varieties and spinach. Contrary to these studies, the genus Alkanindiges comprised approximately a quarter of the abundant $16 \mathrm{~S}$ rRNA gene sequences. While the implications of the variations in the bacterial biodiversity remain to be elucidated, this study has provided a sound protocol for the extraction, performance and analysis of $16 \mathrm{~S}$ rRNA gene sequencing data of epiphytic bacterial DNA from delicate leaf structures, which greatly improves the understanding of the lettuce phyllosphere microbiota.

Acknowledgments: The authors thank Florian Fricke, University of Hohenheim, and Mitja N.P. Remus-Emsermann, Agroscope, for helpful discussions.

This research project was partially supported by the German Ministry of Economics and Technology (via AiF) and the FEI (Forschungskreis der Ernährungsindustrie e.V., Bonn), project number AiF $17122 \mathrm{~N}$.

This cooperation was part of COST Action FA 1202 "A European Network for Mitigating Bacterial Colonisation and Persistence on Foods and Food Processing Environments".

\section{REFERENCES}

ARONESTY, E. 2011. ea-utils: Command-line tools for processing biological sequencing data. http://code.google.com/p/ea-utils/

CAPORASO, J.G., LAUBER, C.L., WALTERS, W.A., BERG-LYONS, D., HUNTLEY, J., FIERER, N., OWENS, S.M., BETLEY, J., FRASER, L., BAUER, M., GORMLEY, N., GILBERT, J.A., SMITH, G., KNIGHT, R. 2012 Ultra-high-throughput microbial community analysis on the Illumina HiSeq and MiSeq platforms. The ISME Journal, 6(8), 1621-1624. http://dx.doi.org/10.1038/ismej.2012.8

CRUAUD, P., VIGNERON, A., LUCCHETTI-MIGANEH, C., CIRON, P.E., GODFROY, A., CAMBON-BONAVITA, M.-A. 2014. Influence of DNA extraction method, 16S rRNA targeted hypervariable regions, and sample origin on microbial diversity detected by 454 pyrosequencing in marine chemosynthetic ecosystems. Applied and Environmental Microbiology, 80(15), 4626-4639. http://dx.doi.org/10.1128/aem.00592-14

DELMOTTE, N., KNIEF, C., CHAFFRON, S., INNEREBNER, G. ROSCHITZKI, B., SCHLAPBACH, R., VON MERING, C., VORHOLT, J.A 2009. Community proteomics reveals insights into the physiology of phyllosphere bacteria. Proceedings of the National Academy of Sciences of the United States of America, 106(38), 16428-16433. http://dx.doi.org/10.1073/pnas.0905240106

DERAKSHANI, M., LUKOW, T., LIESACK, W. 2001. Novel bacterial lineages at the (sub)division level as detected by signature nucleotide-targeted recovery of the 16S rRNA genes from bulk soil and rice roots of flooded rice microcosms. Applied and Environmental Microbiology, 67(2), 623-631. http://dx.doi.org/10.1128/aem.67.2.623-631.2001

DESANTIS, T.Z., HUGENHOLTZ, P., LARSEN, N., ROJAS, M., BRODIE E.L., KELLER, K., HUBER, T., DALEVI, D., HU, P., ANDERSEN, G.L. 2006. Greengenes, a chimera-checked 16S rRNA gene database and workbench compatible with ARB. Applied and Environmental Microbiology, 72(7), 50695072. http://dx.doi.org/10.1128/aem.03006-05

DOJKA, M.A., HUGENHOLTZ, P., HAACK, S.K., PACE, N.R. 1998 Microbial diversity in a hydrocarbon- and chlorinated-solvent-contaminated aquifer undergoing intrinsic bioremediation. Applied and Environmental Microbiology, 64(10), 3869-3877.
EDGAR, R.C. 2010. Search and clustering orders of magnitude faster than BLAST. Bioinformatics, 26(19),

2460-2461.

http://dx.doi.org/10.1093/bioinformatics/btq461

ENYA, J., SHINOHARA, H., YOSHIDA, S., NEGISHI, T.T.H., SUYAMA, K. TSUSHIMA, S. 2007. Culturable leaf-associated bacteria on tomato plants and their potential as biological control agents. Microbial Ecology, 53(4), 524-536 http://dx.doi.org/10.1007/s00248-006-9085-1

ERLACHER, A., CARDINALE, M., GROSCH, R., GRUBE, M., BERG, G 2014. The impact of the pathogen Rhizoctonia solani and its beneficial counterpart Bacillus amyloliquefaciens on the indigenous lettuce microbiome. Frontiers in Microbiology, 5, Article http://dx.doi.org/10.3389/fmicb.2014.00175

FINKEL, O.M., BURCH, A.Y., ELAD, T., HUSE, S.M., LINDOW, S.E., POST, A.F., BELKIN, S. 2012. Distance-decay relationships partially determine diversity patterns of phyllosphere bacteria on tamarix trees across the Sonoran desert. Applied and Environmental Microbiology, 78(17), 7818-7818. http://dx.doi.org/10.1128/aem.02505-12

FINKEL, O.M., BURCH, A.Y., LINDOW, S.E., POST, A.F., BELKIN, S. 2011 Geographical location determines the population structure in phyllosphere microbial communities of a salt-excreting desert tree. Applied and Environmental Microbiology, 77(21), 7647-7655. http://dx.doi.org/10.1128/aem.05565-11

GREEN, P. 2005. Methylobacterium. In: BRENNER, D.J., KRIEG, N.R., STALEY, J.T. (Eds), Bergey's Manual of Systematic Bacteriology. Second edition, vol. 2. Springer; New York, Dordrecht, Heidelberg, London: 567-571. ISBN: 0-387-24145-0. http://dx.doi.org/10.1007/0-387-29298-5 136

HAUBEN, L., SWINGS, J. 2005. Genus XIII. Erwinia. In: BRENNER, D.J., KRIEG, N.R., STALEY, J.T. (Eds), Bergey's Manual of Systematic Bacteriology. Second edition, vol. 2. Springer; New York, Dordrecht, Heidelberg, London: 670-679. ISBN: 0-387-24145-0.

HUNTER, P.J., HAND, P., PINK, D., WHIPPS, J.M., BENDING, G.D. 2010 Both leaf properties and microbe-microbe interactions influence within-species variation in bacterial population diversity and structure in the lettuce (Lactuca species) phyllosphere. Applied and Environmental Microbiology, 76(24), 8117 8125. http://dx.doi.org/10.1128/aem.01321-10

IZHAKI, I., FRIDMAN, S., GERCHMAN, Y., HALPERN, M. 2013. Variability of bacterial community composition on leaves between and within plant species Current Microbiology, 66(3), 227-235. http://dx.doi.org/10.1007/s00284-0120261-X

KADIVAR, H., STAPLETON, A.E. 2003. Ultraviolet radiation alters maize phyllosphere bacterial diversity. Microbial Ecology, 45(4), 353-361. http://dx.doi.org/10.1007/s00248-002-1065-5

KIM, H., NISHIYAMA, W., KUNITO, T., SENOO, K., KAWAHARA, K. MURAKAMI, K., OYAIZU, H. 1998. High population of Sphingomonas species on plant surface. Journal of Applied Microbiology, 85(4), 731-736. http://dx.doi.org/10.1111/j.1365-2672.1998.00586.x

KNIEF, C., DELMOTTE, N., CHAFFRON, S., STARK, M., INNEREBNER, G., WASSMANN, R., VON MERING, C., VORHOLT, J.A. 2012 Metaproteogenomic analysis of microbial communities in the phyllosphere and rhizosphere of rice. The ISME Journal, 6(7), 1378-1390 http://dx.doi.org/10.1038/ismej.2011.192

KUNIN, V., ENGELSBREKTSON, A., OCHMANN, H., HUGENHOLTZ, P. 2010. Wrinkles in the rare biosphere: pyrosequencing errors can lead to artificial inflation of diversity estimates. Environmental Microbiology, 12(1), 118-123. http://dx.doi.org/10.1111/j.1462-2920.2009.02051.x

LEE, Z.M.-P., BUSSEMA, C., SCHMIDT, T.M. 2008. rrnDB: documenting the number of rRNA and tRNA genes in bacteria and archaea. Nucleic Acids Research, 37(suppl. 1), D489-D493. http://dx.doi.org/10.1093/nar/gkn689

LINDOW, S.E., BRANDL, M.T. 2003. Microbiology of the phyllosphere Applied and Environmental Microbiology, 69(4), 1875-1883. http://dx.doi.org/10.1128/aem.69.4.1875-1883.2003

LOPEZ-VELASCO, G., WELBAUM, G.E., BOYER, R.R., MANE, S.P., PONDER, M.A. 2011. Changes in spinach phylloepiphytic bacteria communities following minimal processing and refrigerated storage described using pyrosequencing of $16 \mathrm{~S}$ rRNA amplicons. Journal of Applied Microbiology, 110(5), 1203-1214. http://dx.doi.org/10.1111/j.1365-2672.2011.04969.x

MUMMEY, D.L., STAHL, P.D. 2003. Candidate division BD: phylogeny, distribution and abundance in soil ecosystems. Systematic and Applied Microbiology, 26(2), 228-235. http://dx.doi.org/10.1078/072320203322346074 PRICE, M.N., DEHAL, P.S., ARKIN, A.P. 2010. FastTree 2 - approximately maximum-likelihood trees for large alignments. Public Library of Science one, 5(3), e9490. http://dx.doi.org/10.1371/journal.pone.0009490

RASTOGI, G., SBODIO, A., TECH, J.J., SUSLOW, T.V., COAKER, G.L. LEVEAU, J.H.J. 2012. Leaf microbiota in an agroecosystem: spatiotemporal variation in bacterial community composition on field-grown lettuce. The ISME Journal, 6(10), 1812-1822. http://dx.doi.org/10.1038/ismej.2012.32

REDFORD, A.J., BOWERS, R.M., KNIGHT, R., LINHART, Y., FIERER, N. 2010. The ecology of the phyllosphere: geographic and phylogenetic variability in the distribution of bacteria on tree leaves. Environmental Microbiology, 12(11), 2885-2893. http://dx.doi.org/10.1111/j.1462-2920.2010.02258.x 
REISBERG, E.E., HILDEBRANDT, U., RIEDERER, M., HENTSCHEL, U. 2012. Phyllosphere bacterial communities of trichome-bearing and trichomeless Arabidopsis thaliana leaves. Antonie Van Leeuwenhoek, 101(3), 551-560. http://dx.doi.org/10.1007/s10482-011-9669-8

RHEIMS, H., RAINEY, F.A., STACKEBRANDT, E. 1996. A molecular approach to search for diversity among bacteria in the environment. Journal of Industrial Microbiology, 17(3-4), 159-169. http://dx.doi.org/10.1007/bf01574689

THUNBERG, R.L., TRAN, T.T., BENNETT, R.W., MATTHEWS, R.N., BELAY, N. 2002. Microbial evaluation of selected fresh produce obtained at retail markets. Journal of Food Protection, 65(4), 677-682.

VOKOU, D., VARELI, K., ZARALI, E., KARAMANOLI, K. CONSTANTINIDOU, H.I.A., MONOKROUSOS, N., HALLEY, J.M., SAINIS, I. 2012. Exploring biodiversity in the bacterial community of the mediterranean phyllosphere and its relationship with airborne bacteria. Microbial Ecology, 64(3), 714-724. http://dx.doi.org/10.1007/s00248-012-0053-7

VORHOLT, J.A. 2012. Microbial life in the phyllosphere. Nature Reviews Microbiology, 10(12), 828-840. http://dx.doi.org/10.1038/nrmicro2910

WALTERS, W.A., CAPORASO, J.G., LAUBER, C.L., BERG-LYONS, D. FIERER, N., KNIGHT, R. 2011. PrimerProspector: de novo design and taxonomic analysis of barcoded polymerase chain reaction primers. Bioinformatics, 27(8), 1159-1161. http://dx.doi.org/10.1093/bioinformatics/btr087

WHITE, J.R., NAVLAKHA, S., NAGARAJAN, N., GHODSI, M.R. KINGSFORD, C., POP, M. 2010. Alignment and clustering of phylogenetic markers - implications for microbial diversity studies. BioMed Central Bioinformatics, 11, 152. http://dx.doi.org/10.1186/1471-2105-11-152

WILLIAMS, T.R., MOYNE, A.-L., HARRIS, L.J., MARCO, M.L. 2013. Season, irrigation, leaf age, and Escherichia coli inoculation influence the bacterial diversity in the lettuce phyllosphere. Public Library of Science one, 8(7), e68642. http://dx.doi.org/10.1371/journal.pone.0068642

WILSON, K. 1997. Preparation of genomic DNA from bacteria. Current $\begin{array}{llll}\text { Protocols in } \quad \text { Molecular } & \text { Biology, } & \text { 2.4.1-2.4.5. }\end{array}$ http://dx.doi.org/10.1002/0471142727.mb0204s56 WULFKUEHLER, S., KURFISS, L., KAMMERER, D.R., WEISS, A., SCHMIDT, H., CARLE, R. 2013. Impact of different washing procedures on quality of fresh-cut iceberg lettuce (Lactuca sativa var. capitata L.) and endive (Cichorium endivia L.). European Food Research and Technology, 236(2), 229241. http://dx.doi.org/10.1007/s00217-012-1878-5

WULFKUEHLER, S., STARK, S., DIETZ, J., SCHMIDT, H., WEISS, A., CARLE, R. 2014. Effect of water jet cutting and moderate heat treatment on quality of fresh-cut red oak leaf lettuce (Lactuca sativa L. var. crispa). Food and Bioprocess Technology, 7(12), 3478-3492. http://dx.doi.org/10.1007/s11947-014$\underline{1360-4}$ 